\title{
Research In Vietnam: The Experience Of The Humanities AND Social SCIENCES
}

\author{
Ly Thi Pham ${ }^{\mathrm{a}}$ \\ Vietnam National University, Ho Chi Minh \\ Martin Hayden \\ Southern Cross University
}

\begin{abstract}
Vietnam's low level of research productivity is especially pronounced in the humanities and social sciences. Though previous research has suggested various possible explanations, to date there has been no detailed investigation of the topic. This investigation explored the publishing experiences of a selected sample group of 20 high-achieving and well-regarded Vietnamese scholars from the humanities and social sciences. For these participants, a commitment to research and publishing derived mainly from a personal sense of academic identity, a desire to complement their teaching role by doing research, and a wish to contribute to Vietnam's social and economic development through their research. Few of them reported feeling institutional pressure to publish, though some reported that their university was now providing financial incentives for publishing in high-impact journals. Disincentives to publishing included funding limitations, and especially limitations associated with approval mechanisms within universities. Interference with the freedom to publish was reported to occur, but none of the participants appeared to be too concerned about political censorship. It was widely considered to be easier to have research reported in national than in international peer-reviewed journals because of the difference in academic standards. A lack of confidence with writing in English was also reported by some participants to be a constraint on publishing in international journals.
\end{abstract}

Keywords: higher education, humanities and social sciences, research productivity, Vietnam

\section{Introduction}

Vietnam's research performance, though now making steady progress, continues to fall well short of expectations, given the size of Vietnam's higher education sector and given also that faculty members at public universities in Vietnam are expected to devote one-third of their employment hours to scientific research (Hien, 2010; Nguyen and Pham, 2011; Nguyen, Ho-Le, and Le, 2017; Ministry of Education and Training [MOET], 2014). Many factors have a bearing on this situation. While qualification levels are rising at a rapid pace, it remains the case that over three-quarters of all faculty members do not yet have a doctoral qualification (MOET, 2017). In addition, there has been a tradition in Vietnam for universities to be teaching-only institutions, and many Vietnamese universities have not yet made the conversion to becoming more research-oriented (Pham, 2013). Mechanisms for the distribution of research funds within and between universities in Vietnam have also constrained research productivity because of the cumbersome nature of their administration (Nguyen, 2013; Pham, 2013). In addition, progress with research has tended to be contained by the continuing existence of a large number of small, specialised, mono-disciplinary research institutes which are a legacy of the Soviet period of influence and which function outside the higher education sector. These institutes are not well positioned to contribute to the kinds of large-scale

Correspondence can be directed to: lypham63@gmail.com 
multidisciplinary research projects which increasingly are pivotal to national research and innovation success in Vietnam (Hien, 2010; Pham, 2013).

In the humanities and social sciences, Vietnam's research performance has been especially poor. According to Scimago (2018), only 740 (12.2\%) of the 6,031 cited documents from Vietnam in 2017 came from the humanities and social sciences (including arts and humanities, business and management, economics and finance, psychology, and social sciences). Thailand, in contrast, had a higher proportion (13.6\%), as did Malaysia (34.6\%), and as did Australia, Canada, the Netherlands, the United Kingdom and the United States, each with a proportion ranging from $23.8 \%$ to $31.3 \%$. China, in contrast, had an even lower proportion (5.1\%) than Vietnam.

Despite the fact that research productivity in the humanities and social sciences in Vietnam has been poor, the topic not attracted much more than passing attention in the scholarly literature. Pho and Tran (2016, p. 16), reported on a survey of faculty members from across eight disciplinary areas in the humanities and social sciences at a large university in Ho Chi Minh City. Though the lecturers surveyed appeared to regard research and publishing to be important, their enthusiasm for doing research and for publishing was dampened by perceived obstacles in the form of a lack of funds, a lack of time, and difficulties associated with deciding on a research topic and an appropriate journal in which to publish. When considering the prospect of publishing internationally, they were also concerned about writing in a foreign language, as well as about finding an appropriate journal in which to report their research. Le (2016), whose main focus was the development of an academic identity among lecturers in Vietnam, reported that the main concerns of lecturers from the humanities and social sciences across four site universities in the north of the country were the lack of financial support, a fear that their English skills were not sufficiently well developed for the purposes of publishing in peer-reviewed international journals, and a need felt to avoid research topics which might prove to be politically sensitive. In contrast, lecturers from the natural and applied sciences appeared to be more accomplished, more confident, and more cosmopolitan in their approach to research and publishing (Le, 2016, pp. 158-159). Vuong et al. (2017) addressed factors considered likely to impact on research productivity in the humanities and social sciences. These factors included gender, age, research experience and status as the leading (or corresponding) author. Drawing upon ten years of Scopus data, the researchers concluded that the only variables impacting directly on the academic productivity of scholars in the humanities and social sciences were age and status as a corresponding author.

This investigation seeks to throw more light on the topic. Its specific focus is the publishing experiences of a selected sample group of scholars who were identified by their peers as having achieved, or as being likely to achieve, scholarly prominence within a humanities or social science discipline. Based upon an analysis of these experiences, the investigation identifies circumstances which may be impacting adversely on the publishing profile of accomplished Vietnamese scholars from the humanities and social sciences.

Research performance is defined in this paper as the number of peer-reviewed publications per researcher. As Abramo and D'Angelo (2014) explain, however, this definition is limited in scope because it takes no clear account of publishing quality. A better definition would focus on citations achieved per peer-reviewed publications per researcher. In Vietnam, though, there is no reliable bibliometric data base for the purposes of counting citations, particularly for counting citations for publications written in Vietnamese. It is necessary in this investigation, therefore, to rely on a less informative definition of research productivity.

\section{The Setting}

Vietnam's higher education sector is attracting increased attention in the scholarly literature. Recent accounts of the sector's development have been provided by Pham and Hayden (2015) and by Le and Hayden (2017). There is much to be explained about the sector, but for reasons of brevity only 
three aspects of the sector, each relating closely to the topic of the present investigation, will be addressed here.

The first is that university-based research in Vietnam is acquiring an increased level of status and importance. In 2012, the Higher Education Law declared the need for Vietnam to develop a multi-tiered higher education sector, with research-intensive universities comprising the top tier. This regulatory pronouncement reinforced policy aspirations which have been repeatedly expressed since at least 2005 about the need for Vietnam to have a select group of research-intensive universities capable eventually of achieving 'world-class' status. There are now at least 20 leading public universities in Vietnam that are striving to become 'world-class'. Mechanisms being applied to boost research productivity within these institutions include schemes to provide financial and other rewards for faculty members who succeed in publishing in peer-reviewed international journals. In general, faculty members from the natural and applied sciences have been the leading providers of these kinds of research publications (Le, 2016).

The second is that, though details of the expenditure patterns by the Ministry of Science and Technology are not readily accessible, the flow of public research funds in Vietnam has almost certainly favoured the natural and applied sciences. To an extent, this pattern is inevitable, given Vietnam's need for scientific knowledge to underpin its rapid economic development. The funding advantage given to these scholars has, however, enabled them to achieve a high proportion of all peer-reviewed publications in international journals, and hence to dominate avenues of access to research funds routinely being made available competitively through the National Fund for Science and Technology Development (NAFOSTED), a research funding agency which became operational in 2008. Obtaining funds for research from NAFOSTED requires evidence of prior success in achieving peer-reviewed publications in international journals. Scholars from the humanities and social sciences have been at a relative disadvantage in this regard.

The third is that faculty members in Vietnam do not, in general, have much depth of research experience. Traditionally, universities in Vietnam have been teaching-only institutions, with responsibility for research assigned to specialised public research institutes. Over recent years, the Government has become more supportive of the importance of research in public universities. Under Project 911, for example, 20,000 faculty members are being assisted to obtain doctoral qualifications, with at least one-half of these faculty members permitted to study abroad. The proportion of PhDqualified faculty members (MOET, 2017), though low by international standards at only $21.6 \%$ in 2016, has doubled within the past decade, but these newly-qualified faculty members are not yet experienced as researchers. Furthermore, many of them are assigned to academic management positions, or find that they cannot continue to develop their research skills in Vietnam because of infrastructure and funding deficiencies. The emergence of research-intensive universities is likely, therefore, to be a slower process than policy pronouncements would suggest.

\section{Methodology}

To explore in detail the experiences of publishing by faculty members from the humanities and social sciences, a qualitative investigation requiring the conduct of semi-formal, in-depth interviews with a selected sample group of scholars from across a range of relevant disciplinary backgrounds was designed and implemented. The sampling technique required initially the identification on a convenience basis of a handful of humanities and social science scholars known to the lead author to be highly-regarded researchers in a humanities or social sciences discipline. These scholars were then invited to recommend other scholars for interview. The selection criterion was that the scholars recommended should be already, or should be likely to become, prominent for their research within an academic discipline from the humanities or social sciences.

This 'snowball' sampling technique (Patton, 2002, p. 237) is cost-effective and relatively efficient as a means of recruiting a sample group of suitable participants for a qualitative investigation. A clear limitation, though, is that it is a non-probability form of sampling. Findings generated relate 
exclusively to the perceptions and circumstances of the members of the selected sample group, but that does not mean that the insights discovered are irrelevant to an understanding of the experiences of a wider group of people. It is important, though, that any transfer of insights from this research to other settings is done by the reader, and not by the investigator (Lincoln and Guba, 1985, p. 316).

The interviews took place during the second half of 2017. They continued up until such time as it became evident that data saturation had been reached. At this point, no fresh insights were emerging from the interviews. More than 20 interviews were completed before data saturation became evident. Several interviews had to be discarded, however, because it became apparent that the interviewees concerned had not met the selection criterion. A total of 20 participants were finally selected for inclusion in the investigation.

The research design for the investigation was constructivist and interpretive. Of interest were the individual accounts provided by the participants concerning their personal experiences of academic publishing. These accounts were then analysed for the purposes of extracting key themes. This kind of research design is based on Lincoln and Guba's (1985) methodology of Naturalistic Inquiry, which strongly emphasises the importance of achieving trustworthiness of the findings from an interpretive investigation. Trustworthiness is more likely to be achieved if various standard procedures for the collection and analysis of data are adopted. These procedures include: conducting interviews in a manner which reassures the participants about the importance of the topic and the value of their insights; promising participants that nothing being reported by them will be attributed personally to them; allowing the participants to determine how and when they would like to be interviewed; providing each participant with an opportunity to review the information provided to the researcher; and permitting each the participant to comment on key themes to emerge from the investigation. Each interview was summarised shortly after it took place, and this summary was sent back to the participant in question for verification. Triangulation was also employed by checking significant claims made against relevant documentary and web-based evidence. All research materials collected and developed were maintained in a format suitable for auditing.

Appendix A presents a profile of the 20 participants in the investigation. The participants are referred to by number to preserve their anonymity. Characteristics reported in Appendix A include the participant's field of study, gender and age bracket, academic title and highest academic qualification, and publication details. The extent of descriptive information provided about each participant's publications is restricted to avoid any possibility of the participant concerned being identified.

The participants came from universities located in the north, centre and south of Vietnam except for one participant who was not currently attached to a university. They represented a wide range of disciplines in the humanities and applied social sciences. Fifteen participants had a PhD qualification. Four participants were younger scholars in the process of completing a PhD program - all at foreign universities. Nine participants were female. All the participants had experience of publishing peer-reviewed works, but four of them had published only or mainly in Vietnamese. Several of the participants were well-known and celebrated in Vietnam for their contributions to scholarship in the humanities or social sciences.

Ten of the participants identified themselves as belonging to the humanities. These participants included three whose expertise was based in the discipline of economics. It is unusual for economists to regard themselves as humanities scholars, given the applied nature of most economic research, but these participants insisted that they were mainly interested in the theoretical aspects of economics, and so preferred to identify as humanities scholars.

The interviews were conducted in ways which responded to the preferences of the participants. Some interviews were conducted in person. Most interviews, however, were conducted by telephone. In several cases, the participants preferred to respond by email to the questions in the interview schedule. In general, whether conducted in person, by telephone or through email correspondence, the interviews were successful in obtaining "rich, detailed, and concrete description" (Patton, 2002, p. 473), as is essential to the success of a qualitative investigation. 
Following Spradley's (1979) directions regarding ethnographic interviewing, the guiding questions for the interviews were mostly open-ended, with no restriction placed on how each participant might respond. The questions were as follows:

- What does your current work as an academic involve - teaching? research? administration? Does your work as an academic formally require you to do research?

- Have you published any articles in peer-reviewed academic books or journals? In international or in Vietnamese peer-reviewed academic books or journals? Written in which language (English? Vietnamese? Other?)

- How important is research to you in your role as an academic? Why?

- Have you ever received funding for your research? If so, how much and from which sources?

- What do you see to be the conditions which encourage and support you to produce research outputs?

- What do you see to be the conditions which discourage and constrain you from producing research outputs?

- $\quad$ Could you please share your experiences about the submission of your papers/books/book chapters to domestic and international peer-reviewed journals or similar outlets?

Most interviews were conducted in Vietnamese, the native language of the participants and of one of the authors. Some participants preferred, however, to be interviewed in English, which had become the medium for their scholarly work. Eight interviews were digitally recorded with permission from the participants concerned. All reasonable care was taken during the interviews to ensure that the participants were not exposed to any potential emotional or reputational risks.

\section{Findings}

In the following account, key themes to emerge from the interview data are documented. All participants are referred to simply as lecturers. To retain the authenticity of their comments, the actual words used by participants (translated into English where necessary) are reported.

\section{Valuing Research}

One of the striking features of the comments made by participants was the intensity of their personal attachment to the importance of research. Representative remarks included:

Doing research is natural to me as I do it all my life. It is never boring as it always presents something new. (Participant 4)

Doing research is very important to me. It helps updating knowledge and exchanging ideas with other academics in Vietnam and abroad; it expands our understanding and [allows us to] come to resolutions theoretically and practically; and it supports my teaching role. (Participant 5)

Research plays a critical in my professional career. It helps me improve teaching quality, international exchange, professional development and my findings have contributed to important projects in Vietnam. (Participant 13)

It was clearly the case that one participant after another gained enormous personal satisfaction from an engagement with research. Research was reported by them to have satisfied a passion for discovery, a need to achieve personal professional development, a wish to be a better teacher, and a sense of obligation to contribute to Vietnam's socioeconomic development. In explaining how he felt about research, one of the most published of the participants commented:

My motivation for research . . . includes a passion for discovering meaningfulness as well as for contributing to policy development, supporting learners, and achieving academic 
recognition. At the bottom of my heart, I feel that research is kind of my "karma". I am afraid that if I did not continue to engage with research, my commitment to learning and to work would be wasted. (Participant 1)

His remarks captured most of the elements referred to by the others. Research was important as a foundation stone for personal and professional identity. In addition, it was important in contributing to policy development in Vietnam.

\section{Incentives for Publishing}

The participants' accounts regarding the incentives for undertaking research suggested strongly that their commitment to research was self-motivated. Some participants provided details about incentive schemes devised within individual universities to provide motivation to publish in high-impact international journals. Mostly, though, the participants reported either that they did not know about these schemes or that they were not hugely motivated by them. The main driving force for their engagement with research was said to come from within their own sense of passion for research.

The existence of extrinsic motivators was, however, acknowledged. The participants acknowledged the increasing importance of the role being played by research publications in academic promotion decisions. As one participant reported:

In Vietnam, we have a system that counts the reputation of each journal by a score [an impact factor]. Only publications in highly-scored journals are counted for obtaining promotion to a professorship. The higher the score, the more demanding is the quality of the papers. (Participant 8)

This participant was not alone in recognising the existence of a points system for obtaining advancement to associate professor and to professor appointments. Currently, for example, promotion to associate professor requires the attainment of at least 6 publication points, and promotion to professor requires the attainment of 12 publication points, with points allocated as follows: from 0.25 to 1.0 point for each national publication, and 2.0 points for each peer-reviewed international publication. Of interest here is that all the participants satisfied the publication pointstest for promotion to associate professorship, and most of them also satisfied the points-test for promotion to professorships. Five of the participants were already associate professors, and two were already professors. There are, of course, other requirements for promotion to these academic levels.

Many participants reported, however, that research achievement was not explicitly acknowledged as being important to career success at the universities at which they were employed. One participant explained, for example:

Research is not being appreciated sufficiently in the university environment. It has NOT been a prerequisite for promotion or for obtaining a more senior management role in universities. (Participant 13)

In fact, however, research publications are supposed to be a pre-requisite for promotion to senior academic levels, as documented in Decision No. 20/2012/QĐ-TTg (MOET, 2012). Of interest, therefore, was the fact that Participant 13 and at least six other participants referred to research achievement as not being important to career success. Participant 11 commented, for example: "My major responsibilities are teaching and research. Research is required for this job, but it is not a demand of the institution. I mean, if I did not do research, there would be no problem. I would still keep my job." Participant 2 commented: "My work is teaching, research, and management. I'm encouraged by my institution but not required to do research." It was not uncommon for the participants to refer to an expectation of their employing university that they should be involved 
in research, with at least one-half of them reporting that this expectation existed for them. The prevailing view, though, was that the decision to undertake research, and specifically to produce peer-reviewed publications, was largely a matter of personal choice, with nobody likely to be too concerned if they did not engage in publishing.

Various participants reported on financial incentives being provided within universities to encourage the attainment of research publications. Some of the incentives were remarkably generous. Participant 9, for example, reported that: "The encouragement [to publish] is strong at my institution. My university gives a reward of 40 million VND [about $\$ 1,720$ US Dollars(USD)] per article." Participant 10 reported that his university provided "20 million VND [about \$860 US] per article published in ISI journals." By comparison, the salary for a professor in Vietnam is within the range from USD $\$ 4,800$ US to $\$ 7,200$ per annum. Most participants, however, made no mention of these financial incentive schemes, suggesting either that the schemes were not widespread across the higher education sector or that the incentives were not especially significant in decision making about publishing.

As many as 14 of the participants reported that they had received external funding in support of their research activities. The funds were reported to have come from a remarkably wide range of sources, including ministerial and institutional research grants, grants from NAFOSTED, grants from provincial authorities, and grants from various foreign governments and non-government organizations.

Only three of the participants referred explicitly to the size of the grants received. They reported receiving grants of between USD $\$ 4,000$ and $\$ 6,000$. These participants were among the most highly published of the 20 participants in the investigation.

\section{Disincentives for Publishing}

The participants were invited to comment on what they considered to be the conditions discouraging or constraining them with respect to academic publishing. Participants 7 and 10 reported experiencing no disincentives or constraints on their publishing activities, but these were the exceptions. For a majority of the participants, disincentives and constraints were considered to exist. Participant 19 referred, for example, to the "lack of funding, lack of facilities, lack of support and attention from management, and lack of intellectual freedom." His overview reflected broadly the range of disincentives and constraints reported by many of the other participants.

The lack of funds was referred to by more than one-third of the participants, but seldom in isolation from other related concerns. Participant 4, for example, was concerned not only with the lack of funds but also with deficiencies in the research funding process. She commented: "The funding application process is too complicated and too bureaucratic." Participant 12 also reported on the lack of funds, and he too was critical of the bureaucratic hurdles: "Bureaucratic procedures, especially those related to financial claims and reimbursement." Participant 20 expressed a similar point of view, adding that she had little confidence in the people making the funding decisions: "The research funding procedures are inappropriate. Members of selection boards [for determining grants] are not open-minded, vary greatly in terms of their research knowledge, and operate with no supervision regarding the quality of their decision making." Participant 11 went one step further, claiming that the institutional funding process for research operated under a cloud of corruption: "The research funding mechanisms are weak ... [and] are affected by 'xin-cho' [providing financial benefits in exchange for favourable decisions], which encourages corruption. Officials need postgraduate qualifications to obtain higher-level appointments, but they corrupt the system by not complying with academic norms." Participant 11 was referring here to the fact that government officials were influential in determining the flow of funds to programs and research projects in universities, and so then felt entitled to be able to ask for certain privileges in return.

The question of intellectual freedom was referred to by about one-third of the participants. In general, they expressed confidence that they were able to find ways of avoiding political censorship. 
Of more concern to them was the way in which committees with responsibility for approving institutional research grants and for vetting research publications interfered to the extent of telling individual researchers how they should conduct their research and which findings were important to report. Participant 2, a younger academic who had already acquired extensive international experience, explained the situation as follows:

The constraints do not come from external forces but from people inside the academic system, especially the evaluation committees approving research grants and research results. As a consequence, we have to do things the way they want to see rather than the way we have learned and that are internationally accepted. (Participant 2)

Another participant who was also concerned with institutional impositions on intellectual freedom saw the matter as being symptomatic of a collectivist mind-set which gave rise to a lack of risk-taking by individual scholars. In his view:

The limitation of academic freedom is the major obstacle not only for academic productivity in the social sciences and humanities but also for national human development. I am not talking here about interference by the authorities, but about the barriers that exist within the minds of individual academics. There is a collectivist mind-set which is threatening to individuals who dare to be different. (Participant 15)

In general, while none of the participants referred to blatant political censorship, about onethird of them drew attention to the existence of political sensitivities. Negotiating these sensitivities appeared mainly to be part of the challenge of having research plans approved at an institutional level.

\section{Experiences of Getting Published}

All the participants had something to say about their experiences of getting published. Some accounts were lengthy and detailed. Several key themes emerged.

One of these concerned the nature and extent of the differences between publishing in national and publishing in international peer-reviewed journals. It was widely accepted that it was more difficult to have articles published in international than in national journals. The difference was attributed mainly to the fact that the expectations of international journals were seen to be much higher. Participant 3 commented, for example: "Domestic journals are much easier for getting a paper accepted because there is no language barrier, but the international peer-reviewed journals also have stricter norms and higher standards." Participant 5 added: "It is harder to have our findings published in international peer-reviewed journals because the review process is more strictly implemented." Participant 12 commented: "International journals are more demanding on quality and it is hard to find suitable [international] journals for submission my manuscripts." Some participants noted, however, that the gap was closing, especially in the case of leading national peerreviewed journals. Participant 2 reported, for example: "The peer review procedures of the domestic journals are now almost similar to those of the international ones, though less strict." Participant 5 commented also: "High quality journals in Vietnam have adopted reviewing procedures that follow international norms." Several of the participants were themselves journal editors. They reported how their reviewing procedures increasingly mirrored practices adopted by international journals.

There was extensive speculation about the reasons why it was easier to get papers published in Vietnamese journals. Participant 12 claimed: "Vietnam has the same review process [as in Japan], however it is done superficially because of the lack of a mature academic culture. Reviewers [in Vietnam] do not work in alignment with academic norms but are instead influenced by nonacademic values." Participant 10 , who was remarkably well published in international peer-reviewed journals, referred bluntly to unethical practices: "Peer review in domestic journals is easier. What bothers me, though, is that the quality of research published in this country is questionable. Articles 
are accepted because of a 'relationship' rather than by going through a strict screening." Several others made similar comments. Participant 9, for example, reported: "I used to submit articles to a domestic journal, but the reviewers' comments showed me that they did not know what they were talking about." Participant 5 stated: "Others [Vietnamese journals] remain very easy in reviewing papers - sometimes I do not know if the editors have even read the papers. . The procedure of submission and review is unprofessional, and it is difficult to contact the editors." Participant 2, who was a member of an editorial board, when asked directly if he had heard of editors of Vietnamese journals being bribed to accept articles, responded: "Yes, I have heard such a rumour, but I myself have never experienced that [situation]."

Two participants who were PhD candidates in a developed English-speaking country at the time of the interviews commented from a comparative perspective on their experiences of publishing in Vietnam. Participant 17 was especially detailed in her remarks:

In Vietnam, I only had experience in submitting manuscripts to the journal of our university. I received editors' comments and I did make [edits] to improve the quality of the manuscripts. I think that process [is] acceptable in the context of Vietnam. Submitting papers to international peer review journals is a totally different experience. In an international competition, in order for a paper to be accepted... I need to do [the process] strategically by conducting a quality study - investigating the focus of the journal, board of editors, acceptance rates, potential readers. Receiving [a] rejection letter was not a comfortable experience at all. But right after that, I had to talk to myself: I am not allowed to give up, I am not allowed to let my and other team members' effort to nowhere, and I must find a home for manuscripts.

Participant 16, another PhD candidate at the time of the interviews, also referred to the impact of receiving a rejection letter for an article she had submitted for publication: "For me, learning how to handle peer review, including dealing with rejection, is very important. I myself got rejected several times [and continue to] find [the] peer review stage daunting and demotivating!"

Comments made by various other participants suggested that the incidence of manuscript rejections in Vietnam was much lower. Participant 3, who edited a journal in Vietnam, when asked if she ever rejected manuscripts, responded by saying: "Most of the papers I review are those which [have] already [gone] through a screening process, so their quality[is] usually accepted. Sometimes I review papers written by PhD students, which might be in poor condition and I usually give them very detailed comments." Not immediately evident in these remarks, but consistent with the tone in which they were communicated, was the message that everything possible was done by her and by other journal editors in Vietnam not to reject outright articles submitted for publication. In this regard, journal editors in Vietnam were regarded as being more willing to compromise than journal editors for international journals.

Another key theme to emerge concerned the difficulty of achieving the proficiency levels in English which were generally required by international journals which had English as their medium of communication. Limited English proficiency was also reported to adversely impact upon an ability to understand papers written in English in international journals, that is, when international journals were even able to be accessed from Vietnam. Participant 13 spoke about the problem:

Language capacity is a significant barrier. Accessibility to [an] international literature is also limited in Vietnam. It is difficult, therefore, to catch up with the latest knowledge and developments in the field, and it is difficult to find appropriate topics for research and then publish in reputable [international] journals. This is not a problem for domestic publishing. Publishing in international peer-reviewed journals is harder for humanities and social science scholars, but it is not impossible. If we had resources and an appropriate academic environment, we could publish internationally, though maybe not in the top journals. 
Participant 3, who had studied in Russia, referred more explicitly to the difficulties associated with having a limited mastery of English: "I studied in Russia and have several research articles published in Russian. Later in my career, I studied English, and now I can use English in my work. But publishing in English journals is challenging." Publishing in English was reported to be challenging by most of the participants, but some, such as Participant 1, had become so fluent in English that it had become their working language for research.

Several participants referred to the advantages of obtaining either collegial or professional assistance with English as a basis for getting research papers published less stressfully. Participant 14 reported, for example: "Submission to international journals is hard if we do it alone. Much easier with support of international colleagues/co-authors." Participant 16 commented: "English used in social sciences research tends to have a high level of sophistication. It is so hard to get published in an international outlet without language assistance." Though the matter was not explored systematically with the participants, it did generally appear that, especially in the social sciences, co-authoring papers with an English-speaking colleague enhanced productivity in terms of achieving international publications. For participants in the purely humanities disciplines, such as aesthetics, literature and history, co-authorship was more difficult because their publications were more likely to be concerned with arguing the author's distinctive and creative interpretation of a particular aesthetic, literary or historical phenomenon.

\section{Conclusion}

Vietnam's research performance is generally regarded as being poor. It has been estimated by the Ministry of Science and Technology that Vietnam has about 2,000 organizations engaged in research and development activities, yet Vietnam's performance in terms of research documents produced and patents recorded is not commensurate with either the country's size or the size of its higher education sector (Hien, 2010; Nguyen and Pham, 2011; Nguyen, Ho-Le, and Le, 2017). Vietnam's research performance in the humanities and social sciences is especially poor, and it is against this background that the present investigation was initiated.

The investigation's purpose was to document the publishing experiences of a selected sample group of scholars from the humanities and social sciences with a view to throwing light on these practices. The scholars interviewed were selected on the basis that they had already achieved, or were likely to achieve before too long, prominence for their research within an academic discipline from the humanities or social sciences. These scholars were not, therefore, representative of scholars at large in Vietnam. They represented an elite in the context of the humanities and social sciences in Vietnam, though perhaps the four participants who were PhD candidates could not yet be described in this way, though they had already published extensively.

The participants provided insights relating to a number of matters of specific interest to the investigation, including: institutional expectations regarding an engagement in research and publishing; the nature and extent of their publishing experience to date; the importance attributed to research and publishing with respect to the role of an academic; sources and amounts of research funds received; conditions perceived to be encouraging and supporting, or discouraging and constraining, with respect to the completion of research and the publication of research findings; and experiences of getting published. The data for the investigation were obtained by means of individual, in-depth, semi-structured interviews with the selected participants. These participants represented 10 different disciplinary areas from across the humanities and social sciences.

Various attributes of the participants have been highlighted in the paper. One of these was the strength of their personal commitment to the importance of research and publishing. This commitment was based on a personal sense of academic identity, a desire to complement teaching responsibilities, and a wish to contribute to Vietnam's social and economic development. Curiously, 
though, few participants reported feeling pressure from their own university to publish, though many of them reported that doing research was formally an expectation placed on all faculty members. Universities were reported to provide financial incentives for obtaining publications in high-impact journals, but this practice did not appear to be widespread.

Disincentives to publishing included funding limitations, and perhaps even more importantly, limitations associated with the ways in which research funding was administered within institutions. In general, there was reported to be a lack of transparency in the ways in which research funds were distributed by government agencies, other than NAFOSTED, and within universities. Interference with the freedom to do research and to publish was reported to occur within institutions, but none of the participants appeared to be too concerned about political censorship. They conveyed a well-developed understanding of how far they could go in terms of making claims that might be considered to be politically or socially provocative.

The participants conveyed optimism regarding improvements in the quality of peer-reviewed journals in Vietnam, but there was also wide acceptance of the fact that it was easier to have research reported in national than in international peer-reviewed journals, with the standards of scholarship expected by international peer-reviewed journals reported to be demanding. Some participants reported experiencing difficulty in attaining the level of proficiency required to publish in international journals from English-speaking countries.

The findings of the investigation are generally consistent with earlier findings reported by Pho and Tran (2016) and Le (2016). Common themes include a perceived lack of financial support, concern about locating appropriate national and international journals, and feelings of inadequacy regarding the challenge of publishing in a foreign language. However, a big difference between the participants in this investigation and the participants in the other two investigations was that the participants in this investigation were all quite well published compared with most of their peers in the humanities and social sciences. The obstacles and constraints identified by them could not, therefore, be easily dismissed as excuses for not publishing, and so need to be taken more seriously.

There are lessons to be learned from the experiences reported by the participants. First, the process of scholarly publishing in Vietnam needs to attain more trust in the eyes of humanities and social science scholars. Peer-review processes need to reflect better the processes adopted by international journals; the feedback provided by reviewers needs to be better informed and more detailed; members of editorial panels must be selected solely for their scholarly achievements; editors must be willing to reject articles have been judged independently to lack quality; and the developmental potential of scholarly reviews of manuscripts submitted must be more widely cultivated. These needs provide a strong case for professional development programs to be conducted across the higher education sector and within individual institutions, the purpose of which should be to elucidate quality standards relating to the submission, review and publishing of scholarly works.

Second, scholars in the humanities and social sciences in Vietnam require assistance to be able to have their voice heard in the global flow of ideas and information. The main form of assistance required is with English, but they also need to be able to access international journals and participate in international meetings of scholars. Building collaborative publishing partnerships with foreign English-speaking scholars would appear to be a most sensible avenue to pursue. Funds are required to establish scholarly academies in the humanities and social sciences in Vietnam, and these academies must seek to integrate the scholarly community in Vietnam with a global scholarly community. Humanities and social science scholars in Vietnam need to be given opportunities and encouragement to publish their research internationally.

Third, scholarly academies in Vietnam must nurture and protect individualism, in the form of disciplined and creative analysis of social and cultural issues which are of national and international significance. In general, the participants appeared to be unaware of the role scholarly academies in Vietnam might play. These academies must strive to secure academic freedom, so that scholars 
from Vietnam in the humanities and social sciences feel no need even to be self-censoring in the pursuit of knowledge and insights regarding topics of scholarly significance.

\section{References}

Abramo, G., and D'Angelo, C. A. (2014). How do you define and measure research productivity? Scientometrics 101(2), pp. 1129-1144.

Hien, P. D. (2010). A comparative study of research capabilities of East Asian countries and implications for Vietnam. Higher Education, 60(6), pp. 615-625.

Le, T. K. A. (2016). Developing the Academy in Vietnam: An investigation of the formation of academic identity by university lecturers in Vietnam. Unpublished PhD thesis: Southern Cross University, Lismore, Australia.

Le, T. K. A. and Hayden, M. (2017). The road ahead for the higher education sector in Vietnam. Journal of International and Comparative Education, 6(2), pp. 77-89.

Lincoln, Y. S. and Guba, E. G. (1985). Naturalistic Inquiry. Beverly Hills, California: Sage Publications.

Ministry of Education and Training (MOET). (2012). Decision No. 20/2012/QD-TTg, dated April 27, 2012 on Standards for Appointment and Abolition of Academic Titles of Associate and Full Professors. (Unpublished report).

Ministry of Education and Training (MOET). (2014). Circular No. 47/2014/TT-BGDET, dated December 31, 2014 on the Working Conditions and Benefits for Lecturers. (Unpublished report).

Ministry of Education and Training (MOET). (2017). Report on the Conference on Annual Work of Academic Year 2016-2017 and Major Tasks of Academic Year 2017-2018 of University and College Sectors. (Unpublished report).

Nguyễn, V. T. and Phạm, T. L. (2011). Vai trò của đại học trong nền kinh tế tri thức ở Việt Nam [The Role of University in Knowledge Economy in Vietnam]. In N. B. Châu, P. Darriulat, C. H. Thuần, H. Tụy, N. X. Xanh, and P. X. Yêm (Eds.), Kỷ Yếu Đại Học Humboldt 200 Năm (1810 - 2010): Kinh Nghiệm Thế Giới Và Việt Nam [Two Hundred Years Anniversary of Humboldt University Proceedings: International Practices and Vietnam Experiences]. Vietnam: Tri Thức, pp. 663-682.

Nguyen, T. L. H. (2013). The challenges of developing research resources for leading Vietnamese universities. Higher Education Management and Policy, 24(2), pp. 115-130.

Nguyen, T. V., Ho-Le, T. P. and Le, U. V. (2017). International collaboration in scientific research in Vietnam: an analysis of patterns and impact. Scientometrics, 110(2), pp. 1035-1051.

Patton, M. Q. (2002). Qualitative Research and Evaluation Methods (3 ed.). Thousand Oaks, California: Sage Publications.

Pham, T. L. (2013). Case study: The effectiveness of research and innovation management at policy and institutional levels in Vietnam. In A. Olsson and L. Meek (Eds.), Effectiveness of Research and Innovation Management at Policy and Institutional Levels in Cambodia, Malaysia, Thailand and Vietnam. Paris: OECD, pp. 140-162.

Pham, T. L. and Hayden, M. (2015). Vietnam's higher education in transition: The struggle to achieve potential. In B. Rajika and L. Alessia (Eds.), Asia: The Next Higher Education Superpower? New York: The Institute of International Education, pp.145-160.

Pho, P. D. and Tran, T. M. (2016). Obstacles to scholarly publishing in the social sciences and humanities: A case study of Vietnamese scholars. Publications 4(19), pp. 2-23.

Vuong, Q, Ho, T. M., Vuong, T., Napier, N. K., Thu-Trang, V., Napier, N. K., Hiep, H. P. and Ha, V. N. (2017). Gender, age, research experience, leading role and academic productivity of Vietnamese researchers in the social sciences and humanities: exploring a 2008-2017 Scopus dataset. European Science Editing, 43(3), pp. 51-55.

Scimago. (2018). Country Rankings. Available at http://www.scimagojr.com/countryrank.php. [Accessed 23 August 2017].

Spradley, P. J. (1979). The Ethnographic Interview. Florida: Holt, Rinehart and Winston, Inc. 


\section{Appendix A}

\section{Profile of the Participants}

\begin{tabular}{|c|c|c|c|c|}
\hline $\begin{array}{l}\text { Participant } \\
\text { Number }\end{array}$ & $\begin{array}{l}\text { Field of } \\
\text { Study }\end{array}$ & $\begin{array}{c}\text { Gender and } \\
\text { Age Bracket } \\
\text { in Years }\end{array}$ & $\begin{array}{l}\text { Academic Title } \\
\text { and Highest } \\
\text { Academic } \\
\text { Qualification }\end{array}$ & Publication Details \\
\hline 1 & Economics & $\begin{array}{l}\text { Male } \\
30-35\end{array}$ & $\begin{array}{l}\text { Assoc. Prof. } \\
\text { PhD }\end{array}$ & $\begin{array}{l}\text { More than } 100 \text { peer-reviewed articles and } \\
\text { reports in international books and journals, } \\
\text { and multiple reports and conference papers } \\
\text { written in English and Vietnamese for scholarly } \\
\text { audiences globally. }\end{array}$ \\
\hline 2 & Education & $\begin{array}{l}\text { Male } \\
30-35\end{array}$ & $\mathrm{PhD}$ & $\begin{array}{l}\text { More than } 5 \text { peer-reviewed articles in } \\
\text { international journals, and multiple reports and } \\
\text { conference papers written in Vietnamese for } \\
\text { scholarly audiences in Vietnam. }\end{array}$ \\
\hline 3 & Education & $\begin{array}{l}\text { Female } \\
50-55\end{array}$ & $\begin{array}{l}\text { Assoc. Prof. } \\
\text { PhD }\end{array}$ & $\begin{array}{l}\text { More than } 50 \text { peer-reviewed articles in } \\
\text { Vietnamese books and journals, and some peer- } \\
\text { reviewed articles now appearing in international } \\
\text { journals. }\end{array}$ \\
\hline 4 & Education & $\begin{array}{l}\text { Female } \\
55-60\end{array}$ & $\mathrm{PhD}$ & $\begin{array}{l}\text { More than } 10 \text { peer-reviewed articles in } \\
\text { international journals, and multiple reports } \\
\text { and conference papers written in English for } \\
\text { international audiences. }\end{array}$ \\
\hline 5 & Finance & $\begin{array}{l}\text { Female } \\
45-50\end{array}$ & $\begin{array}{l}\text { Assoc. Prof. } \\
\text { PhD }\end{array}$ & $\begin{array}{l}\text { More than } 10 \text { peer-reviewed articles in } \\
\text { international journals, and multiple reports and } \\
\text { conference papers written in Vietnamese for } \\
\text { scholarly audiences in Vietnam. }\end{array}$ \\
\hline 6 & Education & $\begin{array}{l}\text { Female } \\
25-30\end{array}$ & MEd & $\begin{array}{l}\text { More than } 2 \text { peer-reviewed articles in } \\
\text { international journals and more than } 5 \text { reports } \\
\text { and conference papers written in Vietnamese } \\
\text { for scholarly audiences in Vietnam. }\end{array}$ \\
\hline 7 & Education & $\begin{array}{l}\text { Male } \\
25-30\end{array}$ & MEd & $\begin{array}{l}\text { Several peer-reviewed articles in Vietnamese } \\
\text { journals and more than } 5 \text { reports and } \\
\text { conference papers written in Vietnamese for } \\
\text { scholarly audiences in Vietnam. }\end{array}$ \\
\hline 8 & Education & $\begin{array}{l}\text { Female } \\
25-30\end{array}$ & MEd & $\begin{array}{l}\text { Several peer-reviewed articles in Vietnamese } \\
\text { journals and more than } 5 \text { reports and } \\
\text { conference papers written in Vietnamese for } \\
\text { scholarly audiences in Vietnam. }\end{array}$ \\
\hline 9 & Economics & $\begin{array}{l}\text { Male } \\
50-55\end{array}$ & $\begin{array}{l}\text { Assoc. Prof. } \\
\text { PhD }\end{array}$ & $\begin{array}{l}\text { More than } 10 \text { peer-reviewed articles in } \\
\text { international journals, and multiple reports and } \\
\text { conference papers written in Vietnamese for } \\
\text { scholarly audiences in Vietnam. }\end{array}$ \\
\hline 10 & Economics & $\begin{array}{l}\text { Male } \\
40-45\end{array}$ & $\mathrm{PhD}$ & $\begin{array}{l}\text { More than } 60 \text { peer-reviewed articles in } \\
\text { international journals, and more than } 100 \\
\text { reports and conference papers written in } \\
\text { English and Vietnamese for scholarly audiences. }\end{array}$ \\
\hline
\end{tabular}




\begin{tabular}{|c|c|c|c|c|}
\hline 11 & Literature & $\begin{array}{l}\text { Male } \\
35-40\end{array}$ & $\mathrm{PhD}$ & $\begin{array}{l}\text { More than } 10 \text { peer-reviewed articles in } \\
\text { international journals, and multiple reports and } \\
\text { conference papers written in Vietnamese for } \\
\text { scholarly audiences in Vietnam. }\end{array}$ \\
\hline 12 & Geography & $\begin{array}{c}\text { Male } \\
\text { Over } 65\end{array}$ & $\begin{array}{l}\text { Professor } \\
\text { PhD }\end{array}$ & $\begin{array}{l}\text { More than } 30 \text { peer-reviewed articles in } \\
\text { international journals, and more than } 20 \text { reports } \\
\text { and conference papers written in English and } \\
\text { Vietnamese for scholarly audiences. }\end{array}$ \\
\hline 13 & Linguistics & $\begin{array}{l}\text { Male } \\
50-55\end{array}$ & $\begin{array}{l}\text { Assoc. Prof. } \\
\text { PhD }\end{array}$ & $\begin{array}{l}\text { Multiple reports and conference papers } \\
\text { written in Vietnamese for scholarly audiences } \\
\text { in Vietnam, and more than } 3 \text { peer-reviewed } \\
\text { articles in international journals. }\end{array}$ \\
\hline 14 & Economics & $\begin{array}{l}\text { Female } \\
50-55\end{array}$ & $\mathrm{PhD}$ & $\begin{array}{l}\text { More than } 5 \text { peer-reviewed publications in } \\
\text { international journals, and more than } 30 \\
\text { reports, and conference papers written in } \\
\text { English and Vietnamese for scholarly audiences. }\end{array}$ \\
\hline 15 & Linguistics & $\begin{array}{c}\text { Male } \\
\text { Over } 65\end{array}$ & $\begin{array}{l}\text { Professor } \\
\text { PhD }\end{array}$ & $\begin{array}{l}\text { More than } 3 \text { books written in Vietnamese, } \\
\text { and many articles written in Vietnamese for } \\
\text { scholarly audiences. }\end{array}$ \\
\hline 16 & Education & $\begin{array}{l}\text { Female } \\
30-35\end{array}$ & MEd & $\begin{array}{l}\text { More than } 10 \text { peer-reviewed publications } \\
\text { in international journals, and more than } 10 \\
\text { papers presented in English and Vietnamese to } \\
\text { scholarly audiences. }\end{array}$ \\
\hline 17 & Education & $\begin{array}{l}\text { Female } \\
45-50\end{array}$ & MEd & $\begin{array}{l}\text { More than } 5 \text { peer-reviewed publications in } \\
\text { international journals and books, and more than } \\
10 \text { papers presented in English and Vietnamese } \\
\text { to scholarly audiences. }\end{array}$ \\
\hline 18 & History & $\begin{array}{l}\text { Male } \\
55-60\end{array}$ & $\mathrm{PhD}$ & More than 5 books in English and Vietnamese. \\
\hline 19 & $\begin{array}{l}\text { Political } \\
\text { Science }\end{array}$ & $\begin{array}{l}\text { Male } \\
40-45\end{array}$ & $\mathrm{PhD}$ & $\begin{array}{l}\text { More than } 15 \text { peer-reviewed publications in } \\
\text { international journals, and more than } 20 \text { papers } \\
\text { presented in English to scholarly audiences. }\end{array}$ \\
\hline 20 & Archaeology & $\begin{array}{l}\text { Female } \\
50-55\end{array}$ & $\mathrm{PhD}$ & $\begin{array}{l}\text { More than } 10 \text { peer-reviewed publications } \\
\text { in Vietnamese journals, more than } 1 \text { peer- } \\
\text { reviewed paper in international journals, and } \\
\text { more than } 3 \text { books in Vietnamese. }\end{array}$ \\
\hline
\end{tabular}

